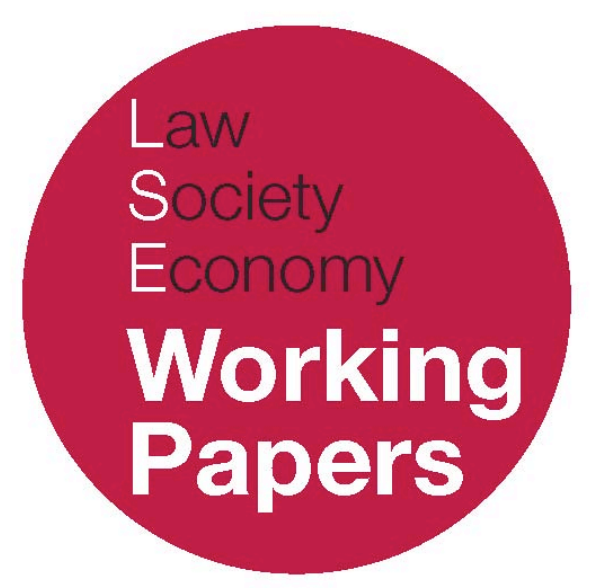

\title{
Transitional Problems in Brudner's Inclusive Conception of Liberalism
}

\author{
John Charvet
}

LSE Law, Society and Economy Working Papers 3/2009

London School of Economics and Political Science

Law Department

This paper can be downloaded without charge from LSE Law, Society and Economy Working Papers at: www.lse.ac.uk/collections/law/wps/wps.htm and the Social Sciences Research Network electronic library at: http://ssrn.com/abstract=1331373.

(C) John Charvet. Users may download and/or print one copy to facilitate their private study or for non-commercial research. Users may not engage in further distribution of this material or use it for any profit-making activities or any other form of commercial gain. 


\title{
Transitional Problems in Brudner's Inclusive Conception of Liberalism
}

\author{
John Charvet
}

\begin{abstract}
This paper criticizes Brudner's purported dialectical deduction and hence "justification" of a communitarian form of liberalism. Brudner's argument begins from an atomistic and libertarian conception of liberalism as the idea of individuals having independent worth as self-sufficient agents. It attempts to show that the contradictions in such a view require resolution, first, through a move to the notion of the equal worth of individuals as autonomous beings and, finally, through the contradictions within egalitarianism to the subsumption of liberty and equality in a liberal community. The point of the deduction is to show that the only conceptually stable and hence viable form of liberalism is communitarian. The paper argues that Brudner's starting-point in independent worth does not express a genuine independence. Equality and community are present implicitly within his initial formulation. Hence, there are no contradictions and no demonstration through their resolution that liberalism, however initially conceived, must end up as communitarian in form. This is not to say that a genuine initial independent individualism cannot be clearly formulated. However, such a position would not generate any supposed contradictions and could lead to a "justification" of a liberal community only on the basis of utilitarian and rational contractarian claims, more in the manner of Hobbes than Hegel.
\end{abstract}

\section{INTRODUCTION}

This paper is concerned with certain connections and oppositions that Brudner perceives between liberty, equality and community. As I understand his project, he begins with a strong atomist conception of the worth of individuals, which he calls

\footnotetext{
* John Charvet is Emeritus Professor of Political Science at the London School of Economics. This paper is part of a collection of essays examining important aspects of Alan Brudner's Constitutional Goods (Oxford: Oxford University Press, 2004). It first appeared as a paper presented at a symposium organized by the LSE Legal \& Political Theory Forum and hosted at the London School of Economics on 9-10 May, 2008. A modified version of this article is published in the current issue of the Canadian Journal of Law and Jurisprudence (2009) 1. The organizers, Philip Cook and Thomas Poole, would like to thank both the LSE and the LSE Law Department for supporting this event.
} 
libertarian, and claims to show how egalitarian and communitarian ideas of individual worth are unavoidably contained in the original idea and must be developed out of it in order to arrive at a coherent and conceptually stable view. This is the inclusive conception, which retains the libertarian and egalitarian moments as subordinate but essential aspects of a liberal ethical community. This paper is sceptical of the validity of the proposed deduction. It concentrates on a few passages, which purport to show how an initial position has implications that nevertheless are in contradiction with the premises from which they are derived. As a result of this concentration, the paper, unavoidably, ignores a great wealth of illuminating material that, together with the impressive sweep of the project as a whole, fully justifies the attention the book is receiving, even if, as I believe, the overall argument does not succeed.

\section{THE RELATION BETWEEN LIBERTY AND EQUALITY}

Brudner starts off with a formulation of the liberal idea that, he believes, is thin enough to be shared by liberals of all types. This is the idea that the individual agent possesses final worth ... as a separate individual, distinct from other individuals as well as from ... groups; ... and that the individual's worth is inviolable...." The simplest and emptiest interpretation of this idea is what he calls libertarian atomism. This view conceives the self as 'detached from all the social relationships in which it finds itself enmeshed as a matter of custom ... and claiming worth solely on account of its free agency'. ${ }^{2}$ My first concern is whether Brudner's account of the basic liberal idea actually distinguishes liberalism from other positions that are not necessarily liberal at all. Thus, the conception of the individual agent as a being of final worth could surely be endorsed by non-liberal Christians or Muslims. To reject this suggestion, it might be thought sufficient to say that Christians and Muslims believe that individuals are of worth only insofar as they freely subordinate themselves to God's will. However, it would seem to me that their belief involves the view that, in freely following God's will, individuals fulfil their divine essence and are of final worth. Furthermore, the secular conception of the individual as of final worth cannot mean that the individual murderer as a murderer is of final worth. The individual can be of final worth only in having a rightful will, i.e. a will that respects the equal worth of other agents. So, whatever the phrase 'the individual is of final worth' means, it cannot mean that he is of final worth in respect of his wrongful will as much as in respect of his rightful will.

What would have to be added to the Brudnerian formula to capture the common liberal belief? In my view, one needs to affirm something like the

\footnotetext{
1 A. Brudner, Constitutional Goods (Oxford: Oxford University Press, 2004) at 13.

2 ibid, at 14.
} 
following: that all normal individuals possess a sufficient capacity for autonomy in the pursuit of the good that social outcomes ought to be based on free individual "rightful" choices or where necessary on collective choices that are governed by principles, which can be agreed by all under fair conditions. But any such initial formula would almost certainly undermine Brudner's dialectic, as I hope to show now by exploring his notion of libertarian atomism.

Libertarian atomism presents us with the picture of a world of "selfsupporting selves" who claim to possess worth in themselves and independently of any relation to another. However, they also claim, by virtue of their inherent worth as free agents, that their free choice as it is expressed in their actions contains the authority to restrict the freedom of others. At this point, Brudner appeals to his notion of valid authority, which holds that a 'claim to authority can be validated only by the free recognition thereof of a subject whose independence is reciprocally recognized by the claimant'. This requirement ensures that the first individual cannot establish a right that his freedom restrict the freedom of others without accepting the equivalent right of the other. Hence we arrive at Kant's formulation of the juridical law of equal freedom namely that 'any action is right if it can co-exist with everyone's freedom under a universal law'. Brudner comments on this shift as follows: 'the libertarian conception of public reason turns out to be, not the free choice of the singular agent, but the Law under which the free choice of one agent is rendered compatible with the free choice of others'. ${ }^{3}$

We must now confront the first contradiction. This is between the libertarian premise that 'the individual possesses final worth in isolation, solely by virtue of its own agency' on the one hand and the legal relationship that reconciles one person's freedom with that of others, on the other hand. The latter involves an interdependence of worth claims: 'each gives and receives validation to and from the other'. ${ }^{4}$ Yet, the contradiction is supposed to have arisen through an implication of the atomistic premise. On the face of it, this looks impossible. How could one generate from the statement that the individual's worth is independent of any relation to another the corollary that his worth is dependent on a process of mutual recognition under law? In fact, in my view the corollary can be derived from what seems a contradictory premise only because the formulation of the premise is entirely misleading. The movement from the original premise of independence to one of interdependence proceeds through the individual's claim that his freedom justifies him in restricting the freedom of others. But where does that claim come from? It arises from the individual's assertion that by virtue of his free agency his choices have worth. This claim, however, appeals to a universal rational principle - namely that the choices of free agents have worth. In other words, one individual's choices have worth only insofar as the choices of all the others do also. Hence, we arrive at the formulation according to which the worth

3 ibid, at 66.

4 ibid, at 67. 
of each agent is dependent on the relation established between them through their mutual dependence on the rational principle.

The point I am making is that the supposed initial premise of independent worth is mythical. This is because it is formulated in a universal form in the first place. It is not, on the face of it, the claim that I alone, as this unique singular, have worth, but that $\mathrm{I}$, as a free agent, have worth. So, there should be no surprise when the reference to others is immediately produced. An instructive example of the structure of this argument is to be found in the work of Alan Gewirth. Gewirth's argument amounts to the claim that one cannot hold one's own freedom to be a good without accepting that the freedom of other agents is a good also. This is because the goodness of one's own freedom arises from one's nature as a rational agent and in this respect one is no different from any other rational agent. Gewirth starts with the single agent and moves to the law of equal freedom, but he doesn't pretend that there is any contradiction between the conclusion and the starting-point. On the contrary, his aim is to show that the single agent's worth is dependent on the affirmation of a rational principle that binds him to recognize the equal freedom of others. ${ }^{5}$ There is no genuine contradiction in Brudner's account either for exactly the same reason. There is no genuine independence in the premise.

Perhaps, the self-supporting self should be understood as claiming that only his unlimited freedom has absolute worth and that the freedom of other agents has instrumental or dependent worth. Such megalomania looks absurd, for what could be so great about him that could justify his unique value status? Furthermore, a world of megalomaniacs would contain no inherent logic driving them to advance to a standpoint of mutual recognition as equals. On the contrary, each would think himself entitled to subordinate others to his will. Only if one introduced something like a need for recognition of that entitlement would there exist the possibility of a transformation of the initial situation. But such an assumed need would just be another way of smuggling in a reference to a rational principle that, when developed, would involve the mutual dependence of equally worthy agents. In other words, if there is to be an initial standpoint, in which the worth of one agent is genuinely independent of that of the others, it cannot, at the same time, depend on a principle that effectively denies that independence.

This is not to say that there is no way of formulating the idea of the independent standpoint of a self-supporting self. However, such a standpoint would have to take the form of a principle of universal egoism. It would consist in the affirmation of the worth of each person's freedom to himself alone and would make no claim of right to restrict the freedom of others. In this respect, egoism differs from megalomania. The latter claims the existence of something of absolute worth, namely my freedom, and in its name demands the subordination of other wills. The former recognizes the equal status of all agents but denies that

5 A. Gewirth, The Justification of Egalitarian Justice (1971) 8 American Philosophical Quarterly 331. See also his book Reason and Morality (Chicago: Chicago University Press, 1978) Chs $2 \& 3$. 
any agent possesses absolute worth. As Bernard Williams and others, including myself, have pointed out, it is perfectly coherent for each individual to say, let each look after his own freedom and no-one is under any obligation not to interfere with the freedom of others if he can. In other words, the area of freedom would be a morally free zone. ${ }^{6}$

Selves in this "Hobbesian" world would conceive themselves as genuinely independent. But there would be no way of moving under the force of the concept to a world of mutually restricting equally worthy free choosers. The two worlds would just be different. To get from the "Hobbesian" world to one of moral equality would require the general recognition of the superiority of the latter to the former in terms of the former's own concerns - namely each person's satisfaction of his own interests. The character of such a move would thus not be that of a conceptual implication but rather an empirical and utilitarian calculation together with a contractual commitment to recognize each other as moral equals and hence to accept mutual restrictions on liberty. In this sense, the "egoists" of the independent standpoint are not essentially or irredeemably egoists. They have been formed in some community and have developed moral capacities. But they abstract themselves in thought from this background in order to reflect on just terms of association that all could accept from the point of view of their own basic interests as self-concerned human beings.

\section{EGALITARIANISM AND ITS CONTRADICTIONS}

According to Brudner, the individual's recognition of the dependence of the worth of his freedom on the law of mutual respect for freedom creates an authoritative public reason or common reasonable will. Furthermore, since individuals' equal rights need detailed regulation in regard to their impact on each other, this common will must be expressed through the legislating will of an organized community of rights-holders. ${ }^{7}$ The attempt to elaborate a constitution based on the conception of a community of equals governed by a common will and regulating an equal liberty is the libertarian constitution. It treats individuals' choice as unproblematically valid whatever the conditions under which a person has to choose. The inadequacy of this conception of free choice, however, generates conceptual movement towards an egalitarian notion of the moral community of equals. The underlying idea of the equal worth of choosers is that they are autonomous, self-determining beings, but this idea is belied by the

\footnotetext{
6 B. Williams, 'Egoism and Altruism' in his Problems of the Self (Cambridge: Cambridge University Press, 1973). See also his Ethics and the Limits of Philosophy (London: Fontana Press/Collins, 1985) at 60-64 and J. Charvet, The Idea of an Ethical Community (Ithaca: Cornell University Press, 1995) at 111-113.

${ }^{7} \mathrm{n} 1$ above, at 69-70.
} 
existence of harsh conditions of choice for some people that deprive them of their self-authored character and hence their right to an equal worth. ${ }^{8}$

Brudner believes that the egalitarian constitution generates its own contradiction. This is said to be between an impersonal standpoint, on the one hand, that the individual has to adopt as a reasonable citizen willing laws that could be accepted by all free and equal persons and, on the other hand, the personal standpoint that an autonomous and rational person pursuing his own good necessarily follows ${ }^{9}$ That these two standpoints are different and could come into conflict is certain but that in itself doesn't amount to a contradiction between them. What would constitute a contradiction of sorts would be the complete independence of the two standpoints in the individual's psychology, so that he was supposed to be at the same time and over the same issues both an impersonal will aiming at the general good and a rational egoist solely concerned with his own good. But this is surely a gratuitous assumption. Why shouldn't the individual acknowledge that he must form and pursue conceptions of his good within the limits of just laws that he and all the others could will as free and equal persons? Indeed, this issue arises in regard to the libertarian constitution in the first place. The individual must accept the equal right to freedom of the others and hence limit his freedom by respect for theirs. If he were incapable of that basic move, the libertarian constitution could not have come into being and had its inadequacies revealed. The impartially determined laws would, of course, have to leave the individual an area of personal freedom within which he can pursue his good as he thinks fit. But it is not obvious why Brudner thinks that they would not do so. Rawls's constitution, which he seems to have in mind here, clearly does.

It is possible that Brudner confuses first order impartiality with second order impartiality. But as he refers at one point, albeit in respect of a different matter, to Brian Barry's Justice as Impartiality, in which this distinction is made much of, that hypothesis should be wrong. Second order impartiality requires the individual to adopt a standpoint of impartiality between his interests and those of others only with regard to the determination of fair rules of association and interaction of persons who are naturally concerned to promote their own good within the limits of what they can agree on as fair. Within such rules, they are free to adopt and follow the personal standpoint on their lives. First order impartiality, however, requires the individual to be impartial between himself and others with regard to every act and demands that he give priority to what is best overall when all interests have been impartially considered over what is best for himself. ${ }^{10}$ This would indeed make it impossible for the individual to enjoy an area of personal freedom and would create a contradiction between the impartial and personal standpoints, since the former depends on the flourishing of the latter, which it at the same time prevents. But while first order impartiality is a possible

8 ibid, at 261-263.

9 ibid, at 158 .

10 See B. Barry, Justice as Impartiality (Oxford: Clarendon Press, 1995) at 11; also at 200-207. S. Scheffler discusses the same issues in his Human Morality (Oxford: Oxford University Press, 1992) at 104-111. 
interpretation of utilitarianism, very few utilitarians have adopted it, since it almost certainly wouldn't lead to the best outcome over time. The most famous is Godwin who notoriously required Archbishop Fenelon's valet to save the archbishop, rather than his own father, from a hypothetical fire because of the archbishop's greater capacity to contribute to the general good. ${ }^{11}$

Brudner spends some time attacking a version of egalitarianism called luck egalitarianism. ${ }^{12}$ This view holds that no-one ought to be worse off than another due to circumstances for which he is not responsible. Luck egalitarians apply this principle as much to the luck involved in the unequal distribution of natural assets as to that resulting from the unequal distribution of social and economic ones. To achieve equality the worse off must be compensated. Brudner thinks that the egalitarian community, so understood, could not be assented to by a worthclaiming individual because the principle that governs it is so hostile to individuality. He claims, indeed, that its 'rule would annul all expressions of determinate individuality'. ${ }^{13}$ Since egalitarianism itself would seem to rest on the equal worth of individuality, Brudner must believe that luck egalitarianism is an example of the contradiction he believes is generated by the egalitarian constitution.

Nevertheless, luck egalitarianism does not involve first order impartiality. It purports to promote the individual's responsibility for his choices insofar as these have been made under conditions that satisfy the luck egalitarian principle and are thus fair in treating individuals as of equal worth. There does not seem any reason, then, why luck egalitarianism could not accommodate a personal standpoint within its impartially arrived at principles. The trouble from Brudner's point of view is that luck egalitarianism seeks to annul the differences between people so that the circumstances under which they make their choices are the same. For the luck egalitarians, the choices they make will be attributable purely to their own free will rather than to extraneous circumstance, such as the distribution of natural assets. But for Brudner, the elimination of all differences is the elimination of individuality. This makes sense only on the assumption that what the individual is includes his personality and natural assets and that self-determining choice is meaningful only as the choice of an individual in forming his life understood in the above comprehensive way.

The luck egalitarian can no doubt respond by pointing out that he does not, of course, envisage redistributing persons' natural assets in any physical sense but intends only to make the winners of the natural lottery compensate the losers. So, each person would still have to choose the best life for himself on the basis of his "given" personality and assets but would have his gains taxed to support the asset poor. ${ }^{14}$ Still, the justification for this redistribution is that natural assets are not an

\footnotetext{
11 W. Godwin, Political Justice ed. Isaac Kramnick (Harmondsworth: Penguin Books, 1985) at 169-170.

$12 \mathrm{n} 1$ above, at 255-258.

$13 \mathrm{ibid}$, at 258 .

${ }_{14}$ This in itself could produce obvious injustice if the natural asset rich chose lives that yielded below average financial rewards.
} 
integral part of who a person is and hence to his meaningful choice of a life. Ideally, persons should choose their lives on the basis of being undifferentiated individuals in respect of all their circumstances, which include everything about a person other than his free will. In this sense, Brudner is surely correct that luck egalitarianism is extremely hostile to any meaningful notion of self-forming individuality and hence is in contradiction with its own foundations.

Nevertheless, this opposition is the result of its implausible conception of the person rather than because of an inherent contradiction within egalitarianism between the impartial and personal standpoints. There is scope, as I have argued above, for the recognition of an area of personal freedom even within luck egalitarianism.

Still, it is clear enough that luck egalitarianism restricts personal liberty beyond what many liberals would consider tolerable and has the absurd consequences that have been carefully detailed by Elizabeth Anderson. ${ }^{15}$ Brudner fully endorses Anderson's critique and also follows her alternative account of the nature of the egalitarian community. According to this view, the relation of equality between people should not be seen as determined by a distributive principle governing resources, opportunities, welfare or whatever, but as a social relationship between citizens that consists in all being subject to laws, which are arrived at through an open discussion among equals and are acceptable to everyone. For Anderson, two people are in a relationship of equality when each acknowledges an obligation to justify her actions by principles that are acceptable to the other. ${ }^{16}$

One problem with this idea is that there may not be any principles that all can acknowledge under fair conditions. Indeed, Brudner allows for this possibility in holding that the arguments of his book presuppose the initial acceptance of the formulation of the common liberal belief with which he starts. However, another problem, which applies within the liberal argumentation, is that Anderson's view of equality doesn't actually exclude the possibility that luck egalitarianism is the principle that all could accept in open discussion as governing their relations as equal citizens. If a moral community of equals is committed to the belief in the equal worth of members as autonomous beings and that notion entails luck egalitarianism, then luck egalitarianism would be the principle that is mutually acceptable to all in open discussion. To avoid this conclusion, it would be necessary to give a much more limited interpretation to the notion of the equal worth of persons as autonomous beings. But for Anderson equal moral worth means the power to develop and exercise moral responsibility to cooperate with others according to principles of justice and this again begs the question as to what those principles are.

In rejecting the conception of equal worth as a horizontal relation between individuals, Brudner opposes to it the idea of a vertical relation between authority

15 E. Anderson, 'What is the point of equality?' (1999) 109 Ethics 287.

$16 \mathrm{ibid}$, at 313 . 
and subject in which 'each citizen submits to authority on condition that authority reciprocally submit to the test of self-imposability by an agent whose defining characteristic is its potential for self-authorship and self-rule'. The subject's right, on this view, is a right to 'authority's concern for one's success, not a right to be equally successful with everyone else'. ${ }^{17}$ This conception of equality is concerned with ensuring that everyone has the opportunities and resources to enable them to lead a valued life rather than with the elimination of advantage.. ${ }^{18}$ However, while this conception of the requirements of social justice seems to me an attractive one, I cannot see that it is a compelling interpretation of the idea of the equal worth of autonomous beings.

Brudner's view may be called a weak egalitarian position, if it can be considered egalitarian at all. It sets a minimum standard of social and economic rights sufficient to ensure that everyone has a reasonable opportunity of success in taking responsibility for his life. A strong egalitarian position is one that aims at an equalization of outcomes or equalization of opportunities for success or of capacities. Brudner's claim is that strong egalitarianism involves a selfcontradiction. However, insofar as this is elaborated as a contradiction between the impersonal and personal standpoints, it is not sustainable and although a case can be made for the existence of a contradiction within luck egalitarianism between its grounding in the value of individuality and its actual hostility towards individuality, this arises from the peculiar conception of the person in luck egalitarianism and is not inherent in egalitarianism itself. One could simply assert that, as all persons are of equal worth, it is unfair that those with superior natural talents should enjoy better outcomes or better opportunities than the rest. Hence, autonomy must be exercised subject to the requirements of equality. This may leave autonomy with an excessively limited realm for most people's liking, but is not obviously self-contradictory.

If strong egalitarianism is not self-contradictory, is it at least an inferior interpretation of equal worth than Brudner's weak egalitarianism? Brudner says that equality in this context is to be understood as a vertical relation between subject and authority rather than a horizontal relation between individuals. But this is surely counter-intuitive. Equality describes a horizontal relation between two entities as in $\mathrm{x}=\mathrm{y}$. Furthermore, the minimum standard of welfare envisaged by Brudner expresses a relation of equality only in the sense that all have the same rights to the minimum standard. Clearly, some people enjoy higher standards than this. Why should the right to the minimum standard better articulate the idea of equal worth than the right to equal welfare or to equal opportunities? Surely, the reverse is true. This is not to say that strong egalitarianism should be endorsed. It should be rejected by denying the principle of equal worth. Liberal values can be defended and liberal equality expressed in terms of the right of everyone to decide for himself how he is to live his life within the bounds of an equal freedom - what

$17 \mathrm{n} 1$ above, at 254 .

$18 \mathrm{ibid}$, at 258 . 
career to pursue, what religion to follow, with whom to associate, who to marry and so on - without being subject in such matters to some external authority, while, politically, persons should be bound only by rules that all who value their negative freedom could agree to. All are entitled to such rights because they all have a sufficient capacity for autonomy to take responsibility for their personal and collective lives and it is better that they should exercise this responsibility than that they should be under the direction of some supposedly superior human being. While everyone should be entitled to sufficient welfare to enable him to develop his capacity for autonomy to the minimum level that justifies the idea of the liberal rights, there is no reason to suppose, nor any reason to say, that all persons are equally worthy as autonomous beings. Autonomy being a matter of degree, some clearly have a superior capacity, and others a superior achievement, in running their lives and in contributing to the collective life..

Such a view of the commitments of equality can be defended from the standpoint of a "Hobbesian" as defined in the section on libertarianism above. In order for the egalitarian principle not to involve a despotic rule over the individual, the principle must be capable of being self-imposed by individuals from the standpoint of their independent worth. Brudner claims that this is not possible if egalitarianism is taken to be the sole and absolute constitutional principle of legitimacy. However, as I have argued above, there is no coherent standpoint of independent worth except that of the "Hobbesian" egoist. This standpoint involves no claim to moral worth and so cannot engender a conceptual movement towards egalitarianism. Nevertheless, the "Hobbesian" independent self can recognize that it would be better off in its own terms if it could create, together with others, the moral structure of a community of equals and bind itself to pursue its good through that structure. But this would not involve a commitment to the idea of their equal worth as autonomous beings, because the independent self would only agree to an interpretation of moral equality that was compatible with its basic interests as a self-owner who is responsible for his own life and this would require the retention of a significant sphere of personal liberty and responsibility. It would not agree to the strong egalitarian conception of moral equality, since that conception goes far beyond its nature and interests as a responsible self-owning being. Even behind a Rawlsian veil of ignorance, contractors, knowing the general nature of individuals, would know that strong egalitarianism would not be acceptable to them, and would, consequently, reject the difference principle or any stronger version of egalitarianism.

\section{LIBERTY, EQUALITY AND COMMUNITY}

The idea of community is already present in the libertarian and egalitarian constitutions as the idea of a community of equals who regulate their common life by public reason. Furthermore, such a community cannot just be an ideal. It must 
be actual and hence concrete. It could, in principle, be the actual community of humankind, but, more plausibly, it is actualized in a multiplicity of autonomous communities with their own substantive mores. However, the notion of community in the libertarian and egalitarian constitutions is contradicted by the atomism that both versions of liberalism adopt in respect of the notion of the individual as an end in himself. The autonomous self choosing its own ends is supposed to be independent of community whereas the notion of community that, according to Brudner, transcends this atomism is the one present in Herder and Hegel and re-presented in contemporary communitarianism, which conceives individuals, not as independent atoms, but as dependent for their identities and values on the community in which they have been formed. ${ }^{19}$

Brudner thinks the communitarian idea is best captured by Hegel's notion of ethical life. On this view individuals and community are ends and means to each other. The community, as an entity structured by norms and institutions, lives only through the vehicle of its individual members who, in identifying themselves with the community and its way of life, govern themselves by its values. The individual members are in this sense means to the community's self-realization. At the same time, the community is the means through which individuals are enabled to form and realize ends of their own. This, also, permits the members to endorse the authority claims of the community over their lives from their own point of view. ${ }^{20}$

While the feature of being ends and means to each other is characteristic of all non-atomistic forms of the relation between individual and community in ethical life, nevertheless many past and present forms are illiberal in nature. In such forms, the individuals' adherence to the community's ways and acceptance of its authority consists in an unreflective attachment by persons who do not think of themselves and their ends independently of the identities they have acquired as members. In endorsing the community's authority, they do so as dependent or communal beings. In such cases, the authority of the community over the individual does not meet the standard of justice inherent in the notion of authority itself, as Brudner conceives it. This requires that the subject of the authority be capable of imposing the authority on himself from a standpoint independent of it. If this condition is not satisfied, individuals are not truly ends for the community, since they are not ends of independent worth. Rather they are of worth only as community members.

The full development of ethical life, then, for Hegel and Brudner, requires the formation within the communal structure of the elements of personal liberty as protected and promoted by the civil rights of the members through which they pursue ends of their own choosing. It requires also the element of equality in the form of democratic self-rule through laws which all can accept as equals. How is this community different from that of the libertarian and egalitarian constitutions? In the first place, liberty and equality are supposed to modify each other. It

$19 \mathrm{ibid}$ at $299-300$.

$20 \mathrm{ibid}$, at $302-303$. 
involves a realm of personal liberty qualified by Anderson-type democratic welfare rules acceptable to all as equals. But the more significant claim is that the liberal community is a genuine form of ethical life in which, despite the presence of libertarian and egalitarian forms, their atomism has been transcended. Brudner calls this mediate atomism. I have to say that I am very unclear what mediate atomism is. He says that the mediate atomist rejects immediate atomism as false but 'nonetheless supported as necessary (belonging) to the rule of Law (here the structure of ethical life) and the publicity of public reason.' He goes on to say, 'A new conception of public reason has now come forward. It is the mutual recognition ... of ethical life and the self who claims to be self-supporting. The idea of ethical life submits for public confirmation as the ground of valid worthclaims to the free testimony of the (putatively) self-supporting self who, in seeking reality for its own worth-claim, forms relationships of cold mutual respect, demands that political association be based on equal moral membership and connects with families and cultures all of which instantiate the mutual recognition structure of ethical life and the new conception.' He also says that it involves '.... the confirmation of ethical life's authority out of the mouth of a morally independent self....'21

What this seems to be saying is that in the liberal ethical community the individual, in embracing his liberal civil rights, comes to think of himself as a selfsupporting self of independent worth. However, this claim is false. The individual is dependent for his worth on the liberal community and its structures. Yet, the liberal community engenders these false beliefs through its liberal structures as a necessary part of the scheme through which it validates its authority over its members. The members have to develop the thought of themselves as selfsupporting selves in order to impose on themselves from that standpoint the community's authoritative norms and institutions. But if the individual is not really independent or self-supporting, how can these false beliefs validate anything?

Perhaps, what is meant is that the individual, in taking responsibility for his particular ends by exercising his rights in liberal society, initially thinks of himself as self-supporting but comes to realize the dependence of his worth on the whole scheme of norms and institutions of the liberal community and in doing so, endorses its authority over him. However, he would, then, only be validating it from within the liberal community and as a member of it and not from any independent standpoint. The authority, so recognized, would not be a fully just one.

Brudner's account of (liberal) ethical life seems to be similar to but distinct from Hegel's. As I understand the latter's view, liberal rights in civil society are necessary to develop in the individual the belief that he is an end in himself and a being of absolute worth. But through his participation in civil society's institutions and through them in political society, he comes to realize that it is not as a particular individual that he possesses absolute worth. Only insofar as he identifies

$21 \mathrm{ibid}$, at 319. 
his will with that of the state and sees his particular interests as the means through which the absolutely free will of the state comes to self-consciousness in him, is his end-status vindicated as the vehicle of a universal life. What is similar in the two accounts is the falseness of the initial belief of individuals that they are independent ends as particular individuals. But in Hegel this self-understanding is completely transcended by being transposed onto the community, whereas in Brudner I do not see what is supposed to happen to the false belief. However, it must be admitted that the Hegelian conclusion is hardly compatible with liberal values, as in the following passage:

Since the determinations of ethics constitute the concept of freedom, they are the substantiality or universal essence of individuals who are related to them merely as accidents. Whether the individual exists or not is a matter of indifference to objective ethical life, which alone has permanence and is the power by which the lives of individuals are governed. Ethical life has therefore been represented to nations as eternal justice, or as gods who have being in and for themselves, and in relation to whom the vain pursuits of individuals are merely a play of the waves. ${ }^{22}$

It might be said that this passage refers, not to the fully developed form of ethical life present in the modern state and requiring the liberal rights of civil society and some mode of political representation, but to the unreflective character of naïve ethical life that Hegel attributed to the ancient world. In the latter, there exists an immediate identification of the individual with his community that precludes the moment of separation from community in which the individual conceives himself as an independent end with rights of his own. However, I cannot see any justification for that claim. The passage does not deny the moment of separation. As paragraph 152 goes on to explain:

The self-will of the individual and his own conscience in its attempt to exist for itself and in opposition to the ethical substantiality, have disappeared; for the ethical character knows that the end which moves it is the universal which, though itself unmoved, has developed through its determinations into actual rationality, and it recognizes that its own dignity and the whole continued existence of its particular ends are based upon and actualized within this universal. ${ }^{23}$

As I understand Hegel here, I take him to be saying that the liberal beliefs and forms are necessary to develop the full subjectivity of ethical life in the individual's self-consciousness as the vehicle of the universal.

22 G.W.F.Hegel, The Philosophy of Right (Cambridge University Press, Eng tr, 1991) paragraph 145, at 190.

$23 \mathrm{ibid}$, at 196. 
All these problems would disappear if one accepted as the initial independent standpoint that of the "Hobbesian" egoist who can validate the structure of liberal community from that position. Of course, it will be said that the "Hobbesian" standpoint is one of unreconstructed atomism. But I believe this claim to be false. There is no reason why the sociological truth of the communitarian view cannot be accepted by the "Hobbesian". Individuals develop their rational capacities and self-consciousness through their formation in the ways of thinking and acting of their community. "Hobbesian" individuals begin their lives by being unreflectively embedded in some traditional ways. But every human being with normal capacities can learn to stand back from such embeddedness and reflect on the terms of a just association that could be accepted by everyone in an open discussion. In order for such a construction to generate a result, it would be necessary only to suppose that all could agree on certain general characterizations of human interests and capacities, such as their interests in life, liberty and access to resources and their capacities for rationality, autonomy and morality. In such a construction, the individual's interests are secured only through his commitment to pursue his good within the constraints of the liberal community. In that way, he must serve the community if the community is to be able to serve him. 